\title{
Oea \\ JURNAL PENDIDIKAN GEOGRAFI \\ KEBERADAAN LEMBAGA ADAT KEUJRUEN BLANG DALAM MENINGKATKAN PRODUKSI PADI PETANI MANGGENG ACEH BARAT DAYA
}

\author{
Daska Azis \\ Jurusan Geografi FKIP, Universitas Syiah Kuala \\ hda.unsyiah@gmail.com
}

\begin{abstract}
The farmer community in Aceh is organized in the Keujruen Blang Customary Institution. Keujreun blang is a traditional institution that is quite strategic and has a role and a very big function, especially in increasing the production of rice farming. The formulation of the problem, whether the existence of customary institutions Keujruen blang can improve the yield of rice farming Manggeng Aceh Barat Daya? The study was conducted in 2016 against 54 farmers and 17 respondents Keujruen blang. Data collection using questionnaires, interviews and in-depth observation. Data processing using Likert scale and percentage of respondents' answers to know the existence of Keujruen blang customary institution in improving the yield of Manggeng farmers. The result of the research shows that most (85,5\%) of the respondents' positive answer to the existence of Keujruen blang customary institution can increase the production of paddy farming of Manggeng farmers in order to improve the farming prosperity and food security in the future
\end{abstract}

Keywords: Customary Institution, Keujruen Blang, rice farming, Manggeng

\begin{abstract}
ABSTRAK
Keujreun blang merupakan Lembaga adat yang cukup strategis dan mempunyai peran dan fungsi yang sangat besar khususnya dalam meningkatkan produksi hasil pertanian sawah. Rumusan masalah, apakah keberadaan Lembaga adat Keujruen blang dapat meningkatkan hasil pertanian padi petani Manggeng Aceh Barat Daya? Kajian dilakukan pada tahun 2016 terhadap 54 responden petani dan 17 responden Keujruen blang. Pengumpulan data menggunakan angket, wawancara dan observasi mendalam. Pengolahan data mengggunakan skala likert dan persentase terhadap jawaban responden untuk mengetahui keberadaan Lembaga adat Keujruen blang dalam meningkatkan hasil pertanian padi petani Manggeng. Hasil penelitian diperoleh bahwa sebagian besar (85,5\%) jawaban responden positif terhadap keberadaan Lembaga adat Keujruen blang dapat meningkatan produksi hasil pertanian padi petani Manggeng dalam rangka meningkatkan kesejahteraan pertani dan ketahanan pangan dimasa datang.
\end{abstract}

Kata kunci: Lembaga Adat, Keujruen Blang, Pertanian Padi, Manggeng

\section{PENDAHULUAN}

Aceh merupakan salah satu provinsi yang terletak di kawasan bagian barat wilayah Republik Indonesia, Aceh dikenal sebagai salah satu provinsi yang diberi keistimewaan dalam bidang agama, pendidikan dan adat istiadat. Adat istiadat adalah segala aturan, ketentuan, tindakan yang menjadi kebiasaan secara turun temurun. Dalam masyarakat Aceh terdapat institusi-institusi adat ditingkat gampong dan mukim. Institusi ini juga merupakan lembaga pemerintahan. Dalam kehidupan bermasyarakat, Ureueng Aceh selalu menyelesaikan 
masalah tersebut secara adat yang berlaku dalam masyarakatnya. Pengelolaan sumber daya alampun diatur oleh lembaga adat yang sudah terbentuk.

Lembaga Adat adalah suatu organisasi kemasyarakatan adat yang dibentuk oleh suatu masyarakat hukum adat tertentu mempunyai wilayah tertentu dan mempunyai harta kekayaan tersendiri serta berhak dan berwenang untuk mengatur dan mengurus serta menyelesaikan hal-hal yang berkaitan dengan adat Aceh. Lembaga adat berfungsi sebagai wahana partisipasi masyarakat dalam penyelenggaraan pemerintahan, pembangunan, pembinaan masyarakat dan penyelesaian masalah-masalah sosial kemasyarakatan (dalam Ketentuan Umum Qanun Aceh No. 10 Tahun 2008 tentang Lembaga Adat.

Menurut UUPA, Pasal 98 Ayat 3 terdapat tiga belas lembaga adat yaitu: 1). Majelis Adat Aceh (MAA); 2). Imum Mukim atau nama lain; 3) Imum Chick dan nama lain; 4) Keuchik atau nama lain; 5) Tuha Peut atau nama lain; 6) Tuha Lapan atau nama lain; 7) Imum Meunasah atau nama lain; 8). Keujruen Blang atau nama lain; 9) Panglima Laot atau nama lain; 10) Pawang Glee atau nama lain, 11) Peutua Seuneubok atau nama lain; 12) Haria Peukan atau nama lain, dan 13) Syahbanda atau nama lain.

Blang dalam bahasa Indonesia disebut "sawah" merupakan sebuah hamparan yang ditumbuhi rumput atau padi. Umumnya, sawah digunakan untuk melakukan kegiatan bercocok tanam. Bagi masyarakat Aceh, sawah merupakan sumber utama perokonomian, disamping sumber penghasil pangan atau makanan pokok. Masyarakat Aceh pada umumya hidup dari hasil sawah, sawah di Aceh sama seperti sawah-sawah didaerah lain di indonesia yaitu dibentuk berpetak-petak pada suatu daerah atau tempat. Kebudayaan yang dimiliki oleh masyarakat Aceh telah melahirkan aturan-aturan dalam pelaksanaan kegiatan bertani khususnya dibidang persawahan. Mata pencaharian utama masyarakat Aceh adalah bertani. Untuk mengetahui bagaimana antusiasnya masyarakat Aceh terhadap bertani, tersirat dalam pribahasa yang berbunyi: "seumayang pangulee ibadat, meugo pangulee harekat." Artinya sembahyang (shalat) merupakan ibadah yang utama, tetapi usaha bertani merupakan sumber utama mata pencaharian. Pribahasa lainnya berbunyi "kaya meueh hana meusampe, kaya pade meusempurna" artinya kaya emas tidak mencukupi tetapi kaya padi yang paling sempurna.

Blang dalam bahasa Aceh sering juga disebut paya, yaitu tempat bercocok tanam khususnya padi. Pengelolaan blang dipimpin oleh seorang yang disebut Keujruen Blang. Ia memiliki beberapa perangkat, termasuk kelompok-kelompok tani. Keujruen blang adalah lembaga adat dan hukum yang mengatur dan mengelola segala masalah berhubungan dengan blang (Sawah). Keujruen blang berada di bawah kekuasaan mukim. Berdasarkan latar belakang tersebut peneliti melakukan kajian lebih jauh mengenai "Keberadaan Lembaga Adat Keujuen Blang dalam Meningkatkan Produksi Padi Petani Manggeng Aceh Barat Daya".

\section{METODE PENELITIAN}

Penelitian dilakukan di Manggeng Kabupaten Aceh Barat Daya pada tahun 2016. Populasi dalam penelitian ini adalah seluruh petani di Manggeng dengan sampel sejumlah 54 responden petani padi, 17 responden Keujruen blang. Data penelitian menggunakan Angket, Wawancara dan observasi mendalam terhadap petani dan Lembaga adat Keujruen Blang di 
Manggeng. Penelitian bersifat deskriptif memberikan gambaran tentang fenomena yang terjadi saat ini untuk menjelaskan atau menafsirkan peristiwa atau kejadian masa sekarang yang masih berlangsung. Juga mengadakan studi kepustakaan yaitu mempelajari sejumlah literatur yang berhubungan dan mendukung permasalahan yang dibahas. Untuk menginterpretasikan data yang diperoleh dari angket dihitung frekuensinya dan disusun dalam bentuk tabel kemudian dihitung persentasenya. penelitian tentang keberadaan Lembaga Adat Keujruen Blang dalam meningkatkan hasil pertanian padi di Manggeng. Analisa menggunakan skala likert terhadap jawaban responden diberi pilihan jawaban sangat setuju, setuju, tidak setuju dan sangat tidak setuju atau pilihan lain yang sesuai dengan pernyataan kuesioner. Untuk mengetahui keberadaan Lembaga adat Keujruen blang dalam meningkatkan hasil pertanian padi petani Manggeng Abdya, dengan ukuran Sangat Setuju (76\%-100\%), Setuju (51\%-75\%), Tidak Setuju (26\%-50 \%), Sangat Tidak Setuju $(0 \%-25 \%)$.

\section{HASIL DAN PEMBAHASAN \\ Sejarah Manggeng}

Manggeng sudah ada sejak abad ke-17 menurut literatur beberapa sejarah, jadi bukan berarti Manggeng sebuah Kecamatan yang baru mekar setelah Abdya ada. Dalam dongeng masyarakat setempat dilukiskan bahwa Manggeng berasal dari kata "Ma" yang bearti ibu dalam bahasa Aceh dan "Ngieng" yang berarti melihat. Mulanya yang menghuni daerah ini kebanyakan yang berasal dari Aceh Besar sehingga daerah ini kebanyakan berbahasa Aceh, kemudian baru datang orang-orang yang hijrah dari Minangkabau. Pendatang baru ini menempati daerah pedalaman di Kecamatan Manggeng yang terletak di Pasi Manggeng sehingga saat ini diwilayah tersebut banyak yang berbahasa Aneuk Jame.

Berdasarkan keterangan dari sumber lokal menyebutkan bahwa Kerajaan Manggeng terdiri dari dua buah wilayah uleebalang, yaitu Uleebalang Manggeng dan Uleebalang Bak Weu. Kedua uleebalang itu diperintah oleh raja. Raja pertama yang memerintah di Kenegerian Manggeng itu adalah Datuk Beusa, diyakini masih ada hubungan famili dengan Sultan Iskandar Muda. Pada masa Datuk Beusa menjadi uleebalang Ia mengabungkan uleebalang Bak Weue dengan ibukota Suak Berembang menjadi satu uleebalang Manggeng yang diperintahnya. Setelah bersatu ibukotanya dipindah ke Lamkuta/Tokoh. Setelah Datuk Beusa meninggal, lalu digantikan oleh anaknya, Teuku Datuk Muda. Teuku Datuk Muda digantikan oleh Teuku Datuk Cut Amat, lalu digantikan oleh Teuku Datuk Nyak Dolah. Teuku Datuk Nyak Dolah digantikan oleh Teuku Raja Geh, setelah itu digantikan oleh Teuku Sandang, namun karena Teuku Sandang melakukan sesuatu kesalahan, sehingga ia diasingkan oleh Belanda ke Batavia (Jakarta). Selama ia berada di Batavia yang mengendalikan kerajaan untuk sementara adalah Teuku Cut Mamat (anak Teuku Raja Geh). Tidak begitu lama ia memerintah lalu digantikan oleh Teuku Muda Nana dan pemangku Nyak Blang. Setelah Teuku Sandang kembali dari Batavia, diangkat kembali menjadi raja di Negeri Manggeng. Tidak lama Teuku Sandang memerintah kemudian digantikan oleh Teuku Raja Iskandar pada tahun 1933 dan sekaligus sebagai raja terakhir di Kenegerian Manggeng.

Setelah merdeka, wilayah Uleebalang Bak Weu menjadi Kemukiman Suak Beurembang dan 
wilayah Uleebalang Manggeng menjadi Kemukiman Ayah Gadeng. Akan tetapi karena terlalu luas, sehingga Kecamatan Manggeng dimekarkan menjadi 4 kemukiman. Kenegerian Manggeng menandatangani korte verklaring sebagai tanda tunduk kepada pemerintah Belanda pada tahun 1881.

\section{Luas dan Letak Wilayah}

Manggeng merupakan kecamatan induk di Kabupaten Aceh Barat Daya Provinsi Aceh. Manggeng memiliki luas wilayah sekitar 40,94 $\mathrm{Km}^{2}$ (Sumber: BPS Banda Aceh). Letak Astronomis Kecamatan Manggeng adalah: 3035'50" LU - 3041'0"LU dan 96035'40" BT - 97०6'50" BT dan letak Geografis adalah:

- Sebelah Utara berbatasan dengan Kecamatan Tangan-tangan

- Sebelah Selatan berbatasan dengan Kecamatan Lembah Sabil

- Sebelah Barat berbatasan dengan Samudra Hindia

- Sebelah Timur berbatasan dengan Kecamatan Labuhan Haji Barat Kabupaten Aceh Selatan.

\section{Kondisi Fisik Wilayah}

Manggeng merupakan wilayah dengan ketinggian diatas 1.000 mdpl. Konsentrasi penduduk umumnya terletak sepanjang Jalan Nasional Meulaboh-Tapaktuan. Sebagian kecil yang berdomisili di daerah perbukitan. Gambar 1 menunjukkan pemanfaatan lahan diperuntukan untuk pertanian, perkebunan, pertambangan, dan juga peternakan. Dalam bidang pertanian, Manggeng merupakan salah satu daerah primadona yang potensial untuk dikembangkan dan terkenal sebagai salah satu lumbung padi Aceh Barat Daya, dengan luas sekitar 2.414 ha menghasilkan 17.502 ton padi. Tabel 1 juga menunjukkan luas lahan sawah berdasarkan Gampong.

\section{Keadaan Demografi}

Jumlah penduduk Manggeng pada tahun 2014 tercatat berjumlah 13.388 jiwa, luas wilayah 40,94 km, setiap $\mathrm{km}^{2}$ ditempati penduduk sekitar 327 orang dan sebagian besar petani. Dari segi tenaga kerja produktif dapat dilihat dari kelompok umur seperti dalam Tabel 2.

Masyarakat Manggeng sebagian besar mata pencahariannya sektor pertanian padi, dari 18 Gampong/Desa hanya satu desa yang tidak memiliki persawahan, penduduk desa tersebut sebagai nelayan. Untuk mengetahui jumlah petani berdasarkan masingmasing Gampong pada Tabel 3. Pada Tabel 4 menerangkan Jumlah dan nama Kuejruen Blang Berdasarkan Gampong (Desa).

Tabel 1. Luas hamparan sawah berdasarkan Gampong

\begin{tabular}{rlcllc}
\hline No & \multicolumn{1}{c}{ Desa } & Luas Lahan (ha) & No & \multicolumn{1}{c}{ Desa } & Luas Lahan (ha) \\
\hline 1 & Lhok puntoy & 1178,32 & 10 & Pante Pirak & 400,34 \\
\hline 2 & Seuneulop & 264,29 & 11 & Panton Makmeu & 41,15 \\
\hline 3 & Ladang Panah & 52,68 & 12 & Sejahtera & 86,68 \\
\hline 4 & Pusu Ingin Jaya & 104,85 & 13 & Pante Cermin & 57,51 \\
\hline 5 & Pante Raja & 421,27 & 14 & Ujong Padang & 566,31 \\
\hline 6 & Blang Manggeng & 115 & 15 & Lhueng Baro & 243,8 \\
\hline 7 & Tokoh & 70 & 16 & Kedai & 10,36 \\
\hline 8 & Tengah & 13,21 & 17 & Paya & 62,03 \\
\hline 9 & Padang & 19 & & & \\
\hline
\end{tabular}

Sumber: Balai Penyuluhan Pertanian, Peternakan dan Kehutanan Manggeng 2016 
Gea. Jurnal Pendidikan Geografi, Volume 18, Nomor 2, Oktober 2018.

Tabel 2. Keadaan penduduk berdasarkan kelompok umur

\begin{tabular}{ccc}
\hline Umur & $\mathbf{2 0 1 3}$ & $\mathbf{2 0 1 4}$ \\
\hline $0-14$ & 30,22 & 30,82 \\
\hline $15-64$ & 65,23 & 64,49 \\
\hline $65+$ & 4,56 & 4,67 \\
\hline
\end{tabular}

Sumber: Abdya dalam angka, 2015

Tabel 3. Jumlah Petani di Manggeng berdasarkan Gampong (Desa)

\begin{tabular}{clcclcc}
\hline No & Gampong & Jumlah Petani & No & Gampong & Jumlah Petani \\
\hline 1 & Lhok puntoy & 2,448 & 10 & Pante Pirak & 798 \\
\hline 2 & Seuneulop & 612 & 11 & Panton Makmeu & 81 \\
\hline 3 & Ladang Panah & 154 & 12 & Sejahtera & 178 \\
\hline 4 & Pusu Ingin Jaya & 212 & 13 & Pante Cermin & 141 \\
\hline 5 & Pante Raja & 1086 & 14 & Ujong Padang & 1000 \\
\hline 6 & Blang Manggeng & 317 & 15 & Lhueng Baro & 318 \\
\hline 7 & Tokoh & 150 & 16 & Kedai & 28 \\
\hline 8 & Tengah & 35 & 17 & Paya & 168 \\
\hline 9 & Padang & 67 & & & \\
\hline
\end{tabular}

Sumber: Balai Penyuluhan Pertanian, Peternakan dan Kehutanan Manggeng, 2016

Tabel 4. Jumlah dan nama Kuejruen Blang Berdasarkan Gampong (Desa)

\begin{tabular}{clcl}
\hline No & \multicolumn{1}{c}{ Desa } & Jumlah & \multicolumn{1}{c}{ Nama-nama Keujruen Blang } \\
\hline 1 & Lhok puntoy & 2 & M. Yassin, M. Syarifuddin \\
\hline 2 & Seuneulop & 3 & Riza Asmadi, Kadri, Zainunjas \\
\hline 3 & Ladang Panah & 2 & M. Nur, Daruddin \\
\hline 4 & Pusu Ingin Jaya & 2 & Asri D, M. Kasem \\
\hline 5 & Pante Raja & 3 & Abdul Rauf, Said Rusli, M.Adam \\
\hline 6 & Blang Manggeng & 2 & Zainal, Muktar \\
\hline 7 & Tokoh & 1 & Ruslan \\
\hline 8 & Tengah & 2 & M.Husein, Supardi Apas \\
\hline 9 & Padang & 2 & M. Nasir, M.Yusuf \\
\hline 10 & Pante Pirak & 3 & Ali Basyah, M.sarong, Idrus \\
\hline 11 & Panton Makmeu & 2 & Ali Basyah, Mawardi \\
\hline 12 & Sejahtera & 2 & Amran. T, Abdur Rapa \\
\hline 13 & Pante Cermin & 2 & M.Amin, M.Nur \\
\hline 14 & Ujong Padang & 3 & M. Hamzah, Khalidin, Ibnu Hajar \\
\hline 15 & Lhueng Baro & 2 & Abdullah, Nasli \\
\hline 16 & Kedai & 1 & M. Salem \\
\hline 17 & Paya & 2 & M. Din, Basri \\
\hline
\end{tabular}

Sumber: Balai Penyuluhan Pertanian, Peternakan dan Kehutanan Manggeng 2016

\section{Lembaga Adat Keujruen Blang}

Istilah Lembaga adat merupakan dua rangkaian kata yang terdiri dari kata "Lembaga" dan "Adat". Kata lembaga dalam bahasa Inggris disebut Institution yang bermakna pendirian, lembaga, adat dan kebiasaan. Lembaga dapat diartikan sebagai sebuah istilah yang menunjukkan kepada pola perilaku manusia yang mapan terdiri dari interaksi sosial yang memiliki stuktur dalam kerangka nilai yang relevan. Perda Nomor 7 tahun 2000 tentang Penyelenggaraan Kehidupan Adat, 
diulas seputar lembaga adat, yang menyebutkan bahwa "Lembaga Adat adalah suatu organisasi kemasyarakatan adat yang dibentuk oleh suatu masyarakat hukum adat tertentu, mempunyai wilayah tertentu dan harta kekayaan sendiri serta berhak dan berwenang untuk mengatur dan mengurus serta menyelesaikan hal-hal yang berkaitan dengan adat Aceh". Sampai saat kelembagaan adat di Aceh susunan sebagai berikut:

1. Lembaga pemerintahan mukim yang diketuai oleh Imuem Mukim

2. Lembaga keagamaan yang dipimpin oleh Imuem Meseujid

3. Lembaga musyawarah mukim yang dipimpin oleh Tuha Lapan

4. Lembaga pemerintahan gampong dipimpin oleh Geusyik

5. Lembaga keagamaan digampong dipimpin oleh Imuem Meunasah

6. Lembaga musyawarah gampong dipimpin oleh Tuha Peut

7. Lembaga adat persawahan yang dipimpin oleh Keujruen Blang

8. Lembaga adat laot yang dipimpin oleh Panglima Laot

9. Lembaga adatb perkebunan yang dipimpin oleh Peutua Sineboek

10. Lembaga adat hutan yang dipimpin oleh Panglima Uteun atau Pawang Glee

11. Lembaga adat lalulintas laut yang dipimpin oleh Syahbanda

12. Lembaga adat perdagangan yang dipimpin oleh Haria Peukan.

Dari semua lembaga adat diatas, kejruen blang, panglima laot, pawang glee, peutua seuneubok, haria peukan, dan syahbanda, dulunya merupakan lembaga- lembaga adat sebagai institusi teknis dibawah koordinasi Imeum mukim yang memiliki peran, fungsi dan kewenangan untuk mengatur, mengawasi dan mengelola sumber daya alam sebagai hak ulayat Mukim.
Keberadaan lembaga-lembaga adat tersebut disuatu mukim tergantung pada letak geografi mukim bersangkutan. Sehingga pada suatu mukim ada lembaga adat yang tidak ada pada mukim lainnya. Misalnya, lembaga adat laoet hanya ada pada mukim yang wilayahnya di pesisir laut, lembaga adat sawah hanya ada pada mukim yang ada lahan persawahan. Begitu pula lembaga adat hutan hanya ada pada mukim yang memiliki wilayah hutan. Namun ada pula mukim yang memiliki lembaga adat hutan dan juga lembaga adat laut, jika dikemukiman tersebut terdapat wilayah laut dan gunung.

Lembaga-lembaga adat di Aceh yang hidup dan berkembang secara kultur, historis, dan sosiologis penuh dengan tantangan global dan distorsi sebagai krisis sosial, budaya, ekonomi, dan politik (T. Djuned, 2003:38). Pada umumnya dapat diklasifikasikan dalam dua kelompok, yaitu: a). Kelompok lembaga adat tradisional, seperti kawasan Mukim, kawasan Gampong, kawasan Laot, kawasan Blang (persawahan), kawasan pelabuhan (kesyahbandaran), dan kawasankawasan kecil lainnya. Penanganan/pengelolaan kelompok dilakukan oleh lembaga-lembaga fungsional (fungsionaris adat), seperti Imuem Mukim, Keuchik, Imuem Meunasah, Imuem Chik, Tuha Peut, Tuha Lapan, Panglima Laot, Keujruen Blang, Peutua Seuneubok, Haria Peukan, Syahbanda dan fungsi-fungsi lainnya dalam bentuk yang lebih kecil; b). Kelompok lembaga adat formal (semi pemerintahan). Kelompok lembaga ini sesuai dengan sosiologis kehidupan masyarakat, maka atas legalisasi pemerintah pusat daerah dibentuklah lembaga-lembaga adat dengan Surat Keputusan Gubernur Kepala Daerah Istimewa Aceh. 


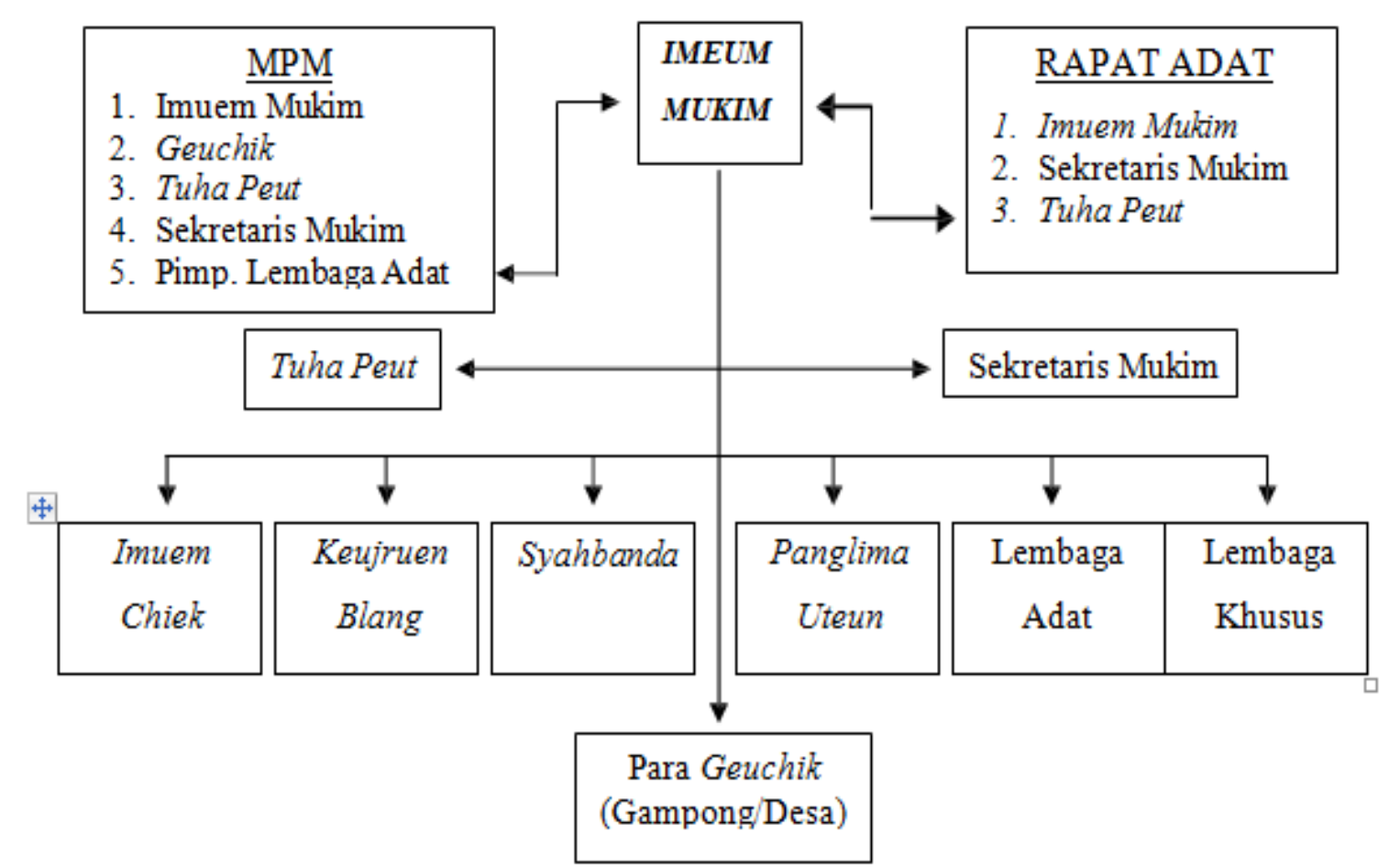

Gambar 1. Lembaga-lembaga Adat di Aceh

Lembaga adat yang berkembang dalam kehidupan masyarakat Aceh sejak dahulu hingga sekarang mempunyai fungsi dan peran dalam membina nilai-nilai budaya, norma-norma adat dan aturan untuk mewujudkan keamanan, keharmonisasian, ketertiban, ketentraman, kerukunan dan kesejahteraan bagi masyarakat Aceh sebagai manifestasi untuk mewujudkan tujuan-tujuan bersama sesuai dengan keinginan dan kepentingan masyarakat setempat. Keberadaan lembaga-lembaga adat di Aceh sebagaimana disebut dalam Pasal 98 ayat 3 UU No. 11 tahun 2006 tentang Pemerintahan Aceh dan Pasal 2 ayat 2 Perda Provinsi Nomor 10 Tahun 2008 tentang Lembaga Adat, hakikatnya memiliki fungsi dan peran sebagai wahana partisipasi masyarakat dalam penyelenggaraan Pemerintahan Aceh dan pemerintahan kabupaten/kota dibidang keamanan, ketenteraman, kerukunan dan ketertiban masyarakat. Adapun fungsi lembaga adat sebagai berikut:
1. Sebagai penampung dan penyalur pendapat atau aspirasi masyarakat kepada pemerintah setempat

2. Sebagai sarana untuk menyelesaikan perselisihan yang menyangkut hukum adat istiadat dan kebiasaan-kebiasaan masyarakat

3. Sebagai pelaksana dalam pemberdayaan, pelestarian dan pengembangan adat istiadat dan kebiasaan-kebiasaan masyarakat dalam rangka memperkaya budaya masyarakat serta memberdayakan masyarakat dalam menunjang penyelenggaraan pemerintahan

4. Sebagai penyokong dalam pelaksanaan pembangunan dan pembinaan kemasyarakatan

5. Sebagai pencipta hubungan yang demokratis dan harmonis serta obyektif antara kepala adat/pemangku adat/ketua adat atau pemuka adat dengan aparat pemerintah setempat

6. Sebagai fasilitator untuk meningkatkan peran aktif masyarakat, terutama dalam 
pengembangan dan pelestarian nilainilai budaya yang ditujukan untuk menjunjung pemberdayaan masyarakat; dan

7. Sebagai lembaga sosial tradisional yang berfungsi untuk menyelesaikan konflik yang terjadi diantara warga masyarakat.

Selain itu, lembaga-lembaga adat tersebut juga memiliki sejumlah kewenangan sebagaimana yang diamanatkan Pasal 4 Qanun (Perda Provinsi Aceh) Nomor 10 Tahun 2008 tentang Lembaga Adat yaitu:

1. Menjaga keamanan, ketenteraman, kerukunan dan ketertiban masyarakat

2. Membantu pemerintah dalam pelaksanaan pembangunan

3. Mengembangkan dan mendorong partisipasi masyarakat

4. Menjaga eksistensi nilai-nilai adat dan adat istiadat yang tidak bertentangan dengan syariat Islam

5. Menerapkan ketentuan adat

6. Menyelesaikan masalah sosial kemasyarakatan

7. Mendamaikan sengketa yang timbul dalam masyarakat

8. Menegakkan hukum adat.

Bagi masyarakat Aceh khususnya di Abdya, adat istiadat memiliki peranan penting dan kedudukan yang sangat tinggi, masyarakat Aceh juga sangat menjunjung tinggi nilai adat istiadat. Hal ini terlihat dengan masih berfungsinya institusi adat ditingkat Mukim dan Gampong. Keberadaan lembaga adat desa juga berfungsi untuk mengayomi dan melestarikan nilai, sistem sosial maupun benda material dari kebudayaan lokal.

\section{Keujruen Blang dan Tugasnya}

Dalam Qanun No.10 tahun 2008 tentang Lembaga Adat, “Keujruen Blang didefinisikan sebagai orang yang memimpin dan mengatur kegiatan usaha dibidang persawahan". Kedudukan keujruen blang sebagai salah satu lembaga adat gampong dibawah mukim yang ikut membantu Geuchik dalam pengelolaan air disawah. Keujruen blang merupakan lembaga adat yang cukup strategis dan mempunyai fungsi dan peran yang sangat besar, khususnya dalam meningkatkan produksi pertanian.

Adapun tugas-tugas Keujruen blang menurut Pasal 25 Qanun Aceh Nomor 10 Tahun 2008 tentang Lembaga Ada, yaitu:

1. Menentukan dan mengkoordinasikan tata cara turun ke sawah;

2. Mengatur pembagian air ke sawah petani;

3. Membantu pemerintah dalam bidang pertanian;

4. Mengkoordinasikan khanduri atau upacara lainnya yang berkaitan dengan adat dalam usaha pertanian sawah;

5. Memberi teguran atau sanksi kepada petani yang melanggar aturan-aturan adat meugoe (bersawah) atau tidak melaksanakan kewajiban lain dalam sistem pelaksanaan pertanian sawah secara adat; dan

6. Menyelesaikan sengketa antar petani yang berkaitan dengan pelaksanaan usaha pertanian sawah.

Berkaitan dengan tugas Keujruen mengkoordinir tata cara turun sawah, di Manggeng terdapat keujruen blang Kecamatan (Keujruen chik) yang bertugas menentukan pelaksanaan turun ke sawah di tingkat Kecamatan, dengan mengadakan rapat koordinasi dengan geuchik, imum mukim, keujruen blang gampong. Dalam rapat membahas hari 
mulai turun ke sawah, hari khanduri blang, masalah pengairan (irigasi, masalah bibit, obat-obatan dan pupuk. Setelah rapat tingkat kecamatan kemudian keujruen blang mengkoordinir para petani sawah untuk gotong royong dalam membersihkan saluran air.

Tugas Keujruen blang untuk mengatur pembagian air ke sawah petani. Manggeng merupakan daerah yang tidak lepas dari keberadaan sumber air yaitu irigasi Lhok Puntoy, irigasi yang pemanfaatannya air untuk memenuhi kebutuhan air pertanian, dengan memperhatikan unsur pemerataan diantara sesama petani. Pengaturan irigasi termasuk didalamnya penutupan pintu air pada saat malam dan siang hari untuk sebagian persawahan. Hal ini dilakukan dengan tujuan agar pembagian dapat disama ratakan ke seluruh sawah. Pengaturan ini sangat berdampak terhadap produksi hasil pertanian padi.

Tugas keujruen blang dalam mengkoordinasikan khanduri blang atau upacara lainnya yang berkaitan dengan adat dalam usaha pertanian sawah. Khanduri blang merupakan tradisi adat Aceh yang biasa dilakukan masyarakat Aceh disetiap gampong secara turun temurun yang diwariskan nenek moyang. Ritual ini sampai sekarang masih dilakukan oleh masyarakat aceh. Tujuan ritual adat khanduri blang adalah sebagai rasa syukur terhadap hasil panen yang berlimpah yang diberikan oleh Allah. Dalam khanduri ini juga dibacakan doa dan zikir yang dipimpin Teungku imuem gampong meminta kepada Allah SWT agar diberikan rahmat dan rezeki agar tanaman yang ditanam bebas dari serangan penyakit. Setelah semua selesai petani memakan nasi bungkus yang sudah dibawa dari rumah.

Keujruen blang memiliki wewenang memberi teguran atau sanksi kepada petani yang melanggar aturanaturan adat meugoe (bersawah) atau tidak melaksanakan kewajiban lain dalam sistem pelaksanaan pertanian sawah secara adat. Pelanggaran terhadap ketentuan yang sudah disepakati dalam rapat koordinasi yang adakan di kecamatan dengan semua pihak-pihak terkait, akan dikenakan sanksi. Adapun bentuk-bentuk pelanggaran yang dikenakan sanksi sebagai berikut:

1. Turun ke sawah tidak sesuai dengan waktu yang telah ditetapkan

2. Pengambilan air yang tidak sah dikenakan sanksi berdasarkan hasil keputusan rapat semua anggota Keujruen blang di Manggeng.

3. Pengerusakan jaringan air dikenakan sanksi memperbaiki kembali seperti semula.

4. Pengerusakan jaringan air karena hewan maka sanksi memperbaiki dikenakan pada pemilik hewan atau kuasanya.

Dari bentuk-bentuk pelanggaran tersebut maka dapat dikenakan sanksi yang berikan oleh pemimpin persawahan (Keujruen blang) terhadap petani yang melanggar aturan, berupa: denda seperti uang, padi atau gabah kering. Keujruen blang mempunyai tugas dalam menyelesaikan sengketa antar petani yang berkaitan dengan pelaksanaan usaha pertanian sawah. Misalnya perkelahian masalah air di sawah maka orang yang pertama yang menyelesaikan sengketa tersebut adalah Keujruen blang berdasarkan hukum adat pertanian sawah yang telah disepakati.

Keujruen blang sangat membantu dalam penyuluhan dan bimbingan yang sangat disegani masyarakat adat. Wewenang dan kekuasaan keujreun blang hanya terbatas pada pengoperasian dan pembagian tali air serta memimpin 
khanduri blang. Menurut Tokoh Belanda Snouch Hugrunje (1985) "Khanduri blang atau khanduri turun ke sawah dimaksudkan untuk kemakmuran tanah bersama yang baru saja menghasilkan, dilaksanakan di awal musim luah blang dihari yang ditetapkan pengurus gampong". Khanduri blang adalah upacara tradisional masyarakat yang dilakukan apabila masyarakat hendak turun ke sawah. Biasanya masyarakat Aceh menyebutnya dengan Khanduri troen $u$ blang (kenduri turun ke sawah). Menurut tradisi di Aceh, apabila melakukan sesuatu hendaknya didahului dengan syukuran termasuk hendak turun ke sawah. Khanduri ini dilaksanakan di sawah sebelum petani memulai mengerjakan sawahnya. Khanduri blang atau Khanduri Babah Lhueng dilaksanakan pada saat air dimasukkan kedalam alur yang mengaliri sawah, dipimpin oleh Keujreun blang dan melibatkan seluruh petani. Khanduri blang diadakan dekat mulut alur dengan cara melakukan pemotongan hewan (biasanya kambing atau kerbau), dan petani membawa nasi serta lauk pauk lainnya guna dimakan bersama sebagai penutup khanduri (Shabri dkk, 2004: 23).

Ada tiga khanduri blang yang dilakukan dengan upacara adat turun ke sawah, yakni khanduri tron u paya, khanduri apam dan khanduri bu: 1). Khanduri Tron U Paya, Kegiatan merupakan upacara adat yang dilakukan saat dimulainya kegiatan turun ke sawah. Biasanya, dalam upacara ini akan dilakukan penyembelihan kerbau (dalam 5 tahun sekali) serta membawa nasi oleh masingmasing aneuk blang (petani sawah). Dalam acara ini, segala peralatan pertanian akan ditepung-tawari. Tepung tawar itu dilakukan usai doa. Sepertiga malamnya dilakukan penanaman padi perdana oleh keujrun blang beserta peutuha gampong, sebagai simbol dimulainya turun ke sawah; 2). Khanduri Apam, Khanduri ini merupakan upacara adat yang dilakukan ketika sudah selesai penanaman padi atau saat padi mulai tumbuh. Dalam upacara ini, setiap aneuk blang diharuskan membawa kue apam atau leumang. Apam merupakan salah satu makanan tradisi di Aceh. Dalam bahasa Indonesia kerap disebut "serabi". Adapun Leumang, biasanya dimasak orang saat meugang. Namun, tatkala turun ke sawah, ada juga makanan tradisional ini. 3). Khanduri Bu, Khanduri ini disebutkan juga dengan Khanduri Bungoeng Padee, yakni upacara adat yang dilakukan ketika padi mulai bunting (beuteng). Dalam upacara ini, setiap aneuk blang diharuskan membawa nasi satu rantang. Khanduri tron u paya, khanduri apam maupun khanduri bu, tujuan utamanya adalah untuk menolak segala bala atau penyakit yang dapat menyerang padi, seperti hama wereng, tikus, ulat padi, burung, dan penyakit padi lainnya.

Upacara-upacara adat ini diisi dengan doa tulak bala, tepung tawar (peusunteng/peusijuk). Sementara makanan dan minuman (nasi, apam, leumang dan kopi) yang dibawa saat kenduri akan dimakan secara bersamasama oleh setiap orang yang hadir. Adapun makanan yang tersisa akan diberikan kepada fakir miskin dan anakanak yatim di daerah tersebut. Prosesnya, beberapa nasi dan apam dimasukkan kedalam timba. Setiap petani akan dipercikkan ke beberapa bagian padi yang sedang tumbuh atau padi yang sedang bunting. Di sela-sela acara berlangsung, keujruen blang atau orang yang dituakan dalam kampung seperti geuchik dan imum chik, akan memberikan arahan mengenai tata cara serta aturan-aturan yang berlaku didalam sawah. Aturan-aturan ini wajib dipatuhi oleh setiap orang, terutama 
aneuk blang. Apabila ada pelanggaran dari aturan yang sudah ditetapkan, si pelanggar akan dikenakan sanksi adat yang berlaku.

Kemudian setelah khanduri selanjutnya ada adat Mmeugoe adalah adat turun mengerjakan sawah. Pada waktu Aceh masih dalam kerajaan, dan mengandalkan pengalaman dan menggunakan peralatan tradisional, termasuk yang berhubungan dengan cuaca, sehingga dibuat hadih maja yang berhubungan dengan cuaca, pada umumnya yang mengetahui akan cuaca ini adalah Keujruen Blang.

Menurut orang-orang tua yang berpengalaman dalam bercocok tanam padi, semua jadwal, cuaca panas dan hujan, begitu juga hama padi, seperti ulat, tikus, walang sangit dan burung serta belalang diperhitungkan musim kawin, musim bertelur, musim menetas/beranak, sebelum penulis membahas adat (peraturan) bersawah ini, terlabih dahulu dijelaskan pengetahuan/ilmu/ pengalaman orang tua tempo dulu dalam menghadapi hambatan/tantangan hama padi disawah. Sebagai berikut:

1. Sebelum turun ke sawah harus diperhitungkan, kapan datangnya musim hujan atau musim kemarau. Sesuia dengan perhitungan kalender Masehi maupun kalender Hijriyah.

2. Harus diperhatikan bulan berapa musim kawin dan beranak tikus sawah, karena tikus sawah akan membuat sarang dalam pematang sawah

1. Dapat mengetahui kapan/ bulan berapa hama serangga bertelur, seperti capung, belalang, kupukupu, walang sangit dan hamahama lainnya, karena apabila telurtelur tersebut menetas akan menjadi ulat membutuhkan makanan yang cukup, yaitu pucuk padi yang masih muda.
2. Untuk padi sistem tadah hujan baik di sawah maupun di ladang sangat penting perhitungan cuaca, karena sejak dari menanam bibit (Benih) sampai pada menanam padi langsung (padi tajok) yaitu menanam padi di dalam lubang, tanpa mendapat gangguan hama maupun kekurangan air.

Menurut T. Djuned (1997) “Figur keujreun blang berasal dari petani yang tekun dan disiplin, berpengalaman dalam bidang kemasyarakatan, menguasai hukum adat pertanian, memahami keuneunong". Menurut Hurgrunje (1985) "berarti keadaan cuaca yang melekat pada setiap bulan masehi, diberi bayangan bahwa musim-musim di Aceh ditentukan menurut kala dan bulan di langit". Pertemuan itulah yang dinamakan keunong (mengenai atau menyentuh) dan masyarakat Aceh menemukan semacam pedoman dalam jumlah hari yang selalu memisahkan bulan baru dari keunong yang selanjutnya atau dengan dengan kata lain (oleh sebab bulan Islam mulai dengan bulan baru) dalam hari terjadinya keunong. Keunenong ini selain sangat terkait dengan musim penghujan dan musim panas/kemarau juga terkaitan dengan musiman hewan kawin dan bertelur. Apabila musiman hama (hewan) berkembang, maka produksi padi tidak mencapai hasil seperti yang diinginkan. Disamping itu, keujreun blang bersama pimpinan adat berwenang mengadili dan memberi sanksi pada pelanggar hukum adat bidang pertanian, baik pada prosesi pelaksanaan, maupun yang berkaitan langsung dengan pelaksanaan adat pertanian.

\section{Peran Keujruen Blang dalam Sistem Persawahan}

Dari hasil penelitian secara mendalam diketahui bahwa Keujrun 
blang berperan dalam segala hal usaha pertanian padi. Hasil angket juga menunjukkan Bahwa responden menjawab sangat setuju berjumlah 28 orang $(51,9 \%)$, setuju berjumlah 26 orang $(48,1 \%)$ dan tidak ada yang menjawab tidak setuju dan sangat tidak setuju. Dengan demikian dapat disimpulkan seluruhnya responden sangat setuju dan satuju bahwa Keujruen blang memiliki peran yang sangat penting dalam sistem persawahan dan pengaturan usaha pertanian padi di Manggeng.

\section{Peran Keujruen Blang sebagai Penghubung Petani dengan Pemerintah}

Keujruen blang berperan sebagai penghubung petani dengan pemerintah. Sebahagian besar responden menjawab sangat setuju berjumlah 19 orang $(35,2 \%)$ dan setuju berjumlah 35 orang $(64,8 \%)$. Tidak ada yang menjawab tidak setuju dan sangat tidak setuju. Dengan demikian dapat disimpulkan bahwa sebagian besar setuju dengan persentase 64,8\% bahwa Keujruen blang berperan sebagai penghubung petani dengan pemerintah atau instansi terkait.

\section{Keujruen Blang Menguasai Hukum Adat dan Memahami Keunenong}

Berdasarkan hasil wawancara dengan responden diketahui bahwa Keujruen blang menguasai hukum adat pertanian dan memahami keunenong dan hasil angket juga dapat disimpulkan bahwa seluruhnya menjawab sangat setuju berjumlah 29 orang $(53,7 \%)$ dan setuju 25 orang $(46,3 \%)$ dan tidak ada yang menjawab tidak setuju dan sangat tidak setuju.

\section{Keujruen Blang dipilih Berdasarkan} Keahlian dalam Pertanian

Dari hasil wawancara danangket diketahui bahwa Keujruen blang dipilih berdasarkan keahlian dalam pertanian.
Responden seluruhnya menjawab sangat setuju berjumlah 23 orang $(42,6 \%)$ dan setuju berjumlah 31 orang $(57,4 \%)$. Dapat disimpulkan bahwa sebagian bahwa keujruen blang dipilih berdasarkan keahlian dalam meningkatkan hasil pertanian padi berdasarkan pengalamannya selama ini yang ditekuni.

Tugas Keujruen Blang dalam Mengatur Pertanian Padi sesuai dengan AturanAturan yang Ditetapkan Pemerintah

Berkaitan dengan tugas Keujruen blang sesuai dengan aturan pemerintah dan Qanun yangmengatur tentang itu, dalam hal ini instansi terkait seperti dinas pertanian dan Badan penyuluhan. Berdasarkan jawaban responden bahwa sangat setuju berjumlah 12 orang $(22,2)$, setuju berjumlah 24 orang $(44,5 \%)$, dan tidak setuju berjumlah 18 orang $(33,3)$. Tidak ada yang menjawab sangat tidak setuju. Dengan demikian dapat disimpulkan bahwa sebagian besar setuju dengan persentase $66,7 \%$ bahwa tugas keujruen blang dalam mengatur pertanian padi sesuai dengan aturanaturan yang telah ditetapkan oleh pemerintah.

\section{Keujruen Blang Mengatur Pembagian Air ke Sawah dengan Baik}

Keujruen blang dalam mengatur pembagian air ke persawahan dengan baik. Berdasarkan jawaban responden diketahui bahwa sangat setuju berjumlah 20 orang $(37,0 \%)$, setuju berjumlah 19 orang $(35,2 \%)$, tidak setuju berjumlah 14 orang $(25,9 \%)$ dan sangat tidak setuju berjumlah 1 orang $(1,9)$. Dengan demikian dapat disimpulkan sebagian besar responden sangat setuju dengan persentase 37,0\% bahwa keujruen blang dapat mengatur pembagian air dengan baik seperti selama ini. 
Keujruen Blang Menentukan Musim bagi Petani Turun ke Sawah.

Dari segi penentuan musim dalam usaha pertanian bagi petani padi terutama dalam penentuan kapan turun kesawah, tanam serentak dan seterusnya sampai panen, Keujruen blang sangat menentukan bagi petani untuk turun ke sawah. Berdasarkan jawaban responden diketahui bahwa responden menjawab sangat setuju berjumlah 16 orang $(29,6 \%)$, setuju berjumlah 37 orang $(68,5 \%)$, tidak setuju berjumlah 1 orang $(1,9 \%)$ dan tidak ada yang menjawab sangat tidak setuju. Dengan demikian dapat disimpulkan sebagian besar responden setuju 98,1\% bahwa Keujruen blang berperan penting yang dapat menentukan musim bagi petani untuk turun ke sawah.

Keujruen Blang yang Menyelesaikan Sengketa Antar Petani yang Berkaitan dengan Pelaksanaan Usaha Persawahan

Dalam menjalan usaha pertanian kadang kala sering terjadi perselisihan antar petani seperti dalam pengaturan pembagian air sawah dan juga hal-hal lain, Keujruen blang yang menyelesaikan sengketa antar petani. Berdasarkan hasil angket bahwa responden menjawab sangat setuju berjumlah 29 orang $(53,7 \%)$, setuju berjumlah 24 orang $(44,4 \%)$, tidak setuju berjumlah 1 orang $(1,9 \%)$ dan tidak ada yang menjawab sangat tidak setuju. Dengan demikian dapat disimpulkan hampir seluruhnya responden sangat setuju bahwa keujruen blang dapat menyelesaikan sengketa antar petani yang berkaitan dengan pelaksanaan usaha pesawahan secara baik.

Keujruen Blang Memberi Sanksi Kepada Petani yang Melanggar Peraturan Adat Pertanian Sawah Berupa Kue dan Memotong Kambing

Dalam pengaturan untuk penegakan aturan atau Qanun, Keujruen blang yang memutuskan dalam memberi sanksi bagi pelanggaran peraturan adat pertanian setempat. Berdasarkan hasil angket diketahui bahwa responden yang menjawab sangat setuju berjumlah 10 orang $(18,5 \%)$, setuju berjumlah 11 orang $(20,4 \%)$, tidak setuju berjumlah 18 orang $(33,3 \%)$ dan sangat tidak setuju berjumlah 15 orang $(27,8 \%)$. Dengan demikian dapat disimpulkan sebagian besar responden tidak setuju dengan persentase $33,3 \%$ bahwa sanksi tersebut dapat memberatkan beban masyarakat petani.

\section{Pelalaksanakan Khanduri Blang Sesuai dengan Keputusan Bersama}

Khanduri blang bagi petani di Manggeng padi sudah menjadi tradisi secara turun temurun dan sudah sepeti kegiatan yang harus dilaksanakan secara bersama. Hal ini sesuai hasil wawancara dan angket diketahui bahwa responden yang menjawab sangat setuju berjumlah 26 orang $(48,1 \%)$, setuju berjumlah 23 orang $(42,6 \%)$, tidak setuju berjumlah 5 orang $(9,3 \%)$ dan tidak ada yang menjawab sangat tidak setuju. Dengan demikian dapat disimpulkan sebagian besar responden sangat setuju dengan persentase $48,1 \%$ bahwa khanduri blang dilaksanakan sesuai dengan keputusan bersama antara keujruen blang dan petan serta menjadi bagian kegitan rutin dilakukan.

\section{Syarat menjadi Keujruen Blang di Manggeng}

Menurut Amran (48) "Setiap masyarakat memiliki hak menjadi keujruen blang, tetapi setelah memenuhi syarat-syarat untuk menjadi keujruen blang" ada syarat-syarat untuk menjadi keujruen blang yaitu, Penduduk asli desa, memiliki lahan pertanian, memahami tentang keuneunong, mengetahui batasanbatasan sawah, adanya gaya kepimpinan serta umur \pm 45 tahun. 
Tugas dan Kesulitan Keujruen blang di Manggeng

Tugas keujruen blang sesuai dengan qanun yaitu mengkoordinasikan tata cara turun ke sawah, mengatur pembagian air ke sawah petani, membantu pemerintah dalam bidang pertanian, mengkoordinasikan upacara yang berkaitan dengan adat dalam pertanian sawah, memberi teguran atau sanksi kepada petani yang melanggar aturan adat meugoe atau tidak melaksanakan kewajiban lain serta menyelesaikan sengketa antar petani.

Kesulitan yang dialami oleh keujruen blang dalam mengatur pertanian padi adalah dalam ketersedian air dan sengketa antar masyarakat tani. Menurut M. Sarong (50) bahwa: Ketersediaan air yang tidak memadai dapat mengganggu aktifitas masyarakat tani. Sehingga dalam memproduksi padi mengalami penurunan, karena air merupakan sumber utama untuk meningkatkan hasil panen padi. Adapun desa yang tidak mendapatkan air, sehingga mereka menggunakan air sumur sendiri untuk menyiram padi dengan menggunakan timba, kejadian tersebut karena keterbatasan air dan sekarang desa tersebut meminta bantuan dari kecamatan tetangga yaitu TanganTangan. Adapun kesulitan lainnya menurut Zainal (38), Adapun masalah antara petani yang dilakukan sedikit kecurangan yang mengakibatkan kesalahpahaman diantara petani. Misalnya dalam satu kawasan yang dipimpin oleh satu keujruen blang terdapat 3-4 kelompok petani. Di kawasan tersebut ada satu kelompok yang mendapatkan bantuan bibit atau pupuk dari pemerintah, sedangkan kelompok lain tidak ada, sehingga terjadinya perselisihan antar kelompok tani.

Untuk meminimalisir masalah
yang terjadi tersebut diperlukan kepemimpinan Keujruen dari peranan yang hanya pada pelaksanaan tugas rutinitas semata ke peran sebagai seorang agen perubahan (change agent) yang mampu melakukan pembaharuan bagi organisasi, pembenahan irigasi, penyadaran masyarakat tani dan kordinasi dengan pemerintah.

\section{Usaha yang dilakukan Keujruen blang dalam meningkatkan hasil padi}

Dalam upaya meningkatkan hasil panen padi segala usaha dapat dilakukan oleh keujruen blang seperti memeriksa bibit padi yang ditanam, pupuk dan mengatur pembagian air secara merata. Menurut Ruslan (45) "Selain bibit padi, pupuk dan pembagian air, 1a juga melakukan usaha yang tidak dilakukan oleh Keujruen blang yang lain yaitu menanam bibit dengan jarak $\pm 20 \mathrm{~cm}^{\prime \prime}$. Ia menyatakan usaha tersebut menghasilkan kemajuan dalam meningkatkan hasil panen padi.

\section{Pendapatan Keujruen blang}

Keujruen blang adalah orang yang memimpin dan mengatur persawahan, atas kerja keras yang ia lakukan berhak mendapatkan upah dari petani dan pemerintah. Keujruen blang menerima hak dari masyarakat tani berupa padi setiap musim panen, hak tersebut tidak ditentukan menurut peraturan pemerintah, tetapi hak yang diterima keujruen blang diberi dengan keikhlasan hati masyarakat tani, kadang kala ada yang tidak memberi hak keujruen blang. Sedangkan menurut peraturan pemerintah masyarakat petani wajib memberi hak keujruen blang. Apabila masyarakat petani memiliki seunaleh umoeng (16 bambu), wajib memberi hak keujruen blang sebanyak senaleh padee (16 bambu padi). Sedangkan dari pemerintah keujruen blang menerima upah berupa uang yaitu 200.000,00 
perbulan, upah tersebut diterima setiap tiga bulan sekali.

Keberadaan Keujruen blang di Manggeng sangat penting dalam meningkatkan hasil pertanian padi. Keujruen blang dapat membantu masyarakat tani dalam menyelesaikan sengketa yang berkaitan dengan persawahan seperti melakukan gotong royong sebelum menanam padi, melaksanakan upacara adat khanduri blang, penanaman padi secara serentak, pemerataan air kesawah-sawah, serta membantu pemerintahan dalam bidang pertanian dan memiliki peran yang sangat penting dalam sistem. Hal ini mengidentifikasikan bahwa keberadaan keujruen blang dalam sistem persawahan sangat penting terutama dalam mengatur pembagian air dengan baik. Hal ini sangat disadari oleh para petani, karena usaha keujruen blang dalam mengatur pembagian air sudah dilakukan secara maksimal.

Dalam penyelesaian sengketa antar petani, keujruen blang yang menyelesaikan sengketa antar petani yang berkaitan dengan pertanian padi. Hal ini mengidentifikasikan bahwa keujruen blang mempunyai tanggung jawab dalam mengatasi konflik antar petani yang berkaitan dengan permasalahan pertanian padi. Berkaitan dengan pemberian sanksi kepada petani yang melanggar peraturan adat berupa kue dan kambing tidak semua masyarakat mampu memenuhi sanksi tersebut dikarenakan keterbatasan ekonomi.

Berdasarkan jawaban responden menjawab sangat setuju $(37,6 \%)$, setuju $(47,9 \%)$ atau sebagian besar responden $(85,5 \%)$ beranggapan positif terhadap keberadaan Lembaga adat Keujruen blang dalam meningkatkan hasil pertanian padi di Manggeng, yang menjawab tidak setuju $(11,5 \%)$ dan sangat tidak setuju $(3,0 \%)$, kecil yang beranggapan negatif mengenai keberadaan lembaga adat keujruen blang dalam meningkatkan hasil pertanian padi. Dengan demikian dapat dikatakan bahwa keberadaan lembaga adat Keujruen blang dapat membantu masyarakat tani dalam meningkatkan hasil panen padi dengan baik.

\section{SIMPULAN}

Keujruen blang merupakan lembaga adat yang mengatur dan mengelola segala masalah berhubungan dengan sawah, setiap peraturan yang telah ditetap oleh keujruen blang wajib dipatuhi. Adapun usaha-usaha keujruen blang yaitu dengan mengatur pembagian air yang merata, memilih bibit padi yang unggul, pupuk serta mengsosialisasikan tata cara penanaman padi dengan baik, atas usaha tersebut keujruen blang wajib mendapat upah baik dari masyarakat tani dan pemerintah.

Adapun kesulitan yang dialami dalam mengatur pertanian padi adalah ketersediaan air yang tidak memadai dapat mengganggu aktifitas masyarakat tani, karena air merupakan sumber utama untuk meningkatkan hasil panen padi. Masalah antar masyarakat petani yang dilakukan sedikit kecurangan yang mengakibatkan kesalahpahaman diantara petani. Untuk meminimalisir kesulitan yang dialami dalam mengatur pertanian padi, diperlukan kepemimpinan yang mampu melakukan pembaharuan bagi organisasi, pembenahan irigasi, penyadaran masyarakat tani dan pemerintah. Dengan demikian keberadaan lembaga adat keujruen blang sangat penting bagi masyarakat di Kecamatan Manggeng.

\section{REKOMENDASI}

Berdasarkan kesimpulan, peneliti mengemukakan saran sebagai berikut:

1. Pemerintah perlu menerapkan peraturan khusus seperti pembagian 
bibit padi, pupuk secara merata agar tidak terjadi konflik antar petani. Pemerintah diharapkan turut serta membantu Keujuren blang dalam mengaliri air ke sawah para petani dengan merata, karena dengan adanya dukungan kerja sama dari pemerintah dapat meningkatkan hasil pertanian.

2. Sebagai pemimpin, dalam menjalankan tugasnya Keujruen blang perlu meningkatkan pengetahuan dan kemampuan pengaturan, pengelolaan sawah dan petani dengan lebih baik agar hasil pertanian padi lebih meningkat, produksi padi sangat ditentukan oleh keberadaan Keujruen blang.

3. Bagi petani diharapkan sebaiknya dapat berkerja sama dengan Keujruen blang dan berkewajiban memberikan hak setiap musim panen atas jerih payah yang dilakukan oleh keujruen blang dalam meningkatkan hasil pertanian padi.

\section{DAFTAR PUSTAKA}

A, Shabri, Rusdi Sufi dan Agus Budi Wibowo. 2004. Keanekargaman Suku dan Budaya di Aceh. Banda Aceh: Balai Kajian Sejarah dan Nilai Tradisional Aceh bekerjasama dengan Badan Perpustakaan Provinsi Nanggroe Aceh Darussalam.

Arikunto, Suharsimi. 2006. Prosedur Penelitian. Jakarta: Rineka Cipta.
Djuned, T. 1977. Penyelesaian Sengketa Menurut Hukum Adat Aceh. Jakarta: Departemen Pendidikan dan Kebudayaan. Direktorat Jendral

Hugrunje, Snouck. 1985. Aceh di Mata Kolonialis. Jakarta: Yayasan Suko Guru.

Reijntjes, Coen, dkk. 2006. Pertanian Masa Depan: Pengantar untuk Pertanian Berkelanjutan dengan Input Rendah cetakan Ke VIII. Yogyakarta: Kanisius.

Sediono, M.P. Tjokronegoro. 2001. "Pengelolaan Sumber Daya Agraria: Kelembagaan dan Reforma Agraria", Jurnal Analisis Sosial, Vol. 2, No.6, hlm. 3.

Siregar, Hadrian. 1981. Budidaya Tanaman Padi di Indonesia: Sastra Hudaya

Sugiyono. 2013. Metode Penelitian Kualitatif (Pendekatan Kuantitatif, Kulitatif, dan RED. Bandung: Alfabeta.

Su'ud, M. Hassan. 2007. Pengantar Ilmu Pertanian. Banda Aceh: Yayasan Pena.

Zuhri, M. 2001. “Kedudukan Lembaga Adat Keujruen Blang dalam Sistem.

Pemerintahan Desa di Aceh", Jurnal Kanun, Vol.11, No. 29, hlm. 1. 